\title{
Synthesis and Spectral Properties of New Octamethyl Substituted Tetrapyrazinoporphyrazines
}

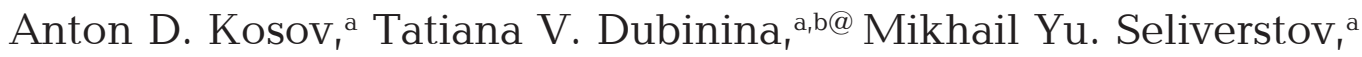 \\ Larisa G. Tomilova, ${ }^{\mathrm{a}, \mathrm{b}}$ and Nikolay S. Zefirov ${ }^{\mathrm{a}, \mathrm{b}}$ \\ ${ }^{a}$ Department of Chemistry, M.V. Lomonosov Moscow State University, 119991 Moscow, Russian Federation. \\ ${ }^{\mathrm{b}}$ Institiute of Physiologically Active Compounds, Russian Academy of Science, 142432 Chernogolovka, Moscow Region, \\ Russian Federation \\ ${ }^{\circledR}$ Corresponding authorE-mail: dubinina.t.vid@gmail.com
}

\begin{abstract}
Efficient synthetic approach to a new magnesium and zinc complexes of methyl substituted tetrapyrazinoporphyrazine was developed. The optimization of reaction conditions for preparation of initial pyrazine-2,3-dicarbonitrile was carried out, using cerium ammonium nitrate as a catalyst. The target complexes were characterized by MALDI-TOF mass spectrometry and NMR spectroscopy. Spectral properties were investigated using UV-Vis and fluorescence spectroscopy.
\end{abstract}

Keywords: Porphyrazine, UV-Vis spectroscopy, fluorescence, microwave irradiation, pyrazine-2,3-dicarbonitrile.

\section{Синтез и спектральные свойства новых октаметилзамещенных тетрапиразинопорфиразинов}

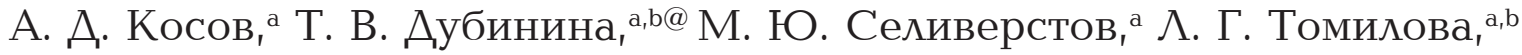 \\ Н. С. Зефирово ${ }^{\mathrm{a}, \mathrm{b}}$
}

${ }^{\mathrm{a}}$ Московский государственный университет имени М.В. Ломоносова, Химический факультет, 119991 Москва,

Российская Федерация

${ }^{\mathrm{b}}$ Институт физиологически активных веществ Российской академии наук, 142432 Черноголовка, Московская обл.,

Российская Федераичия

${ }^{\circledR}$ E-mail: dubinina.t.vid@gmail.com

\begin{abstract}
Разработан эффективный подход $к$ синтезу новых метилзамещченных тетрапиразинопорфиразиновых комплексов магния и ичнка. Оптимизированы условия синтеза исходного пиразин-2,3-дикарбонитрила с использованием изерий аммоний нитрата в качестве катализатора. Целевые соединения охарактеризованы данными масс-спектрометрии MALDI-TOF и ЯМР спектроскопии. Проведено исследование спектральньх свойств с использованием ЭСП и флуоресиентной спектроскопии.
\end{abstract}

Ключевые слова: Порфиразин, ЭСП, флуоресценция, микроволновое облучение, пиразин-2,3-дикарбонитрил. 


\section{Introduction}

Substituted porphyrazines and their metal complexes are widely explored as prospective materials for molecular electronics, ${ }^{[1-3]}$ fluorescent sensors, ${ }^{[4]}$ non-linear optical devices, ${ }^{[5-7]}$ antitumor therapy. ${ }^{[8]}$ Octaazaphthalocyanines, which often termed tetra-2,3-pyrazinoporphyrazines are the most widely studied class of azaanalogues of phthalocyanines. [9-10] Annulation of porphyrazine periphery by electrondeficient pyrazine rings results in n-type conductivity of target pyrazinoporphyrazines. ${ }^{[2,11]}$ High values of secondorder nonlinear optical responses were also demonstrated for substituted pyrazinoporphyrazines. ${ }^{[5,12]}$ Thereby, an effective synthesis of new pyrazinoporphyrazines is an important problem, as well as a study of their properties. The present paper focuses on the synthesis and spectral properties of novel methyl substituted tetrapyrazinoporphyrazines. 5,6-Dimethylpyrazine-2,3-dicarbonitrile was chosen herein as a good model compound for development of synthetic approaches to pyrazinoporphyrazines due to its high availability. In addition, methyl substituents can be readily functionalized to obtain a variety of porphyrazines with improved solubility. Zinc and magnesium were chosen as central ions thanks to their potential ability to remove and give metal-free porphyrazine ligands. ${ }^{[10,13-16]}$

\section{Experimental}

All reagents and solvents were obtained or distilled according to standard procedures. All reactions were TLC and UV/Vis controlled until complete disappearance of the starting reagents if not additionally specified. Preparative TLC was performed using Merck Aluminium Oxide $\mathrm{F}_{254}$ neutral flexible plates. The salt $\mathrm{ZnCl}_{2}$ was dried immediately before use in a vacuum desiccator for $4 \mathrm{~h}$ at $90{ }^{\circ} \mathrm{C}$. The synthesis under microwave irradiation was performed using a Discover LabMate(CEM) device. Electronic absorption (UV-Vis) spectra were recorded on a ThermoSpectronic Helios- $\alpha$ spectrophotometer using quartz cells $(0.5 \times 1 \mathrm{~cm})$. MALDI-TOF mass spectra were taken on a VISION-2000 mass spectrometer with $\alpha$-cyano-4-hydroxycinnamic acid (CHCA) as the matrix.

${ }^{1} \mathrm{H}$ and ${ }^{13} \mathrm{C}$ NMR spectra were recorded on a Bruker AVANCE 400 spectrometer (400.13 and $100.61 \mathrm{MHz}) .{ }^{1} \mathrm{H}$ NMR spectra were also recorded on a Bruker Avance 600 spectrometer $(600.13 \mathrm{MHz})$. Chemical shifts are given in ppm relative to $\mathrm{SiMe}_{4}$.

The fluorescence spectra were recorded on a Cary Eclipse spectrometer in quartz cells $(1 \times 1 \mathrm{~cm})$. Spectral resolution: $\Delta \lambda=1.5 \mathrm{~nm}$.

$\mathrm{Zn}$ (quinoline) ${ }_{2} \mathrm{Cl}_{2}$. Freshly distilled quinoline $(34.00 \mathrm{~g}, 0.3$ $\mathrm{mol}$ ) and dry zinc (II) chloride $(7.30 \mathrm{~g}, 54.0 \mathrm{mmol})$ was heated at $200{ }^{\circ} \mathrm{C}$ during $15 \mathrm{~min}$. After cooling dry diethyl ether $(300 \mathrm{ml})$ was added. White powder obtained was filtered and washed with diethyl ether. This yielded target salt (20.38 g, $96 \%$ ). mp $239^{\circ} \mathrm{C}$ (lit. 237$240{ }^{\circ} \mathrm{C}^{[17]}$ ).

5,6-Dimethylpyrazine-2,3-dicarbonitrile (1). 2,3-Butanedione (0.088 g, $1.02 \mathrm{mmol}), 2,3$-diaminomaleonitrile $(0.11 \mathrm{~g}, 1.0 \mathrm{mmol})$ and cerium ammonium nitrate $(27.40 \mathrm{mg}, 0.05 \mathrm{mmol})$ were stirred in water $(7 \mathrm{~mL})$ at room temperature (TLC-control, $\mathrm{Al}_{2} \mathrm{O}_{3}$, ethyl acetate: $n$-hexane, $2: 1, \mathrm{~V} / \mathrm{V})$. After the reaction was complete the reaction mixture was washed with water $(200 \mathrm{~mL})$. The precipitate was recrystallized from ethanol to give compound $1(0.079 \mathrm{~g}, 51$ \%); mp $110{ }^{\circ} \mathrm{C}$ (lit. $\left.110-112{ }^{\circ} \mathrm{C}^{[18]}\right) .{ }^{1} \mathrm{H} \mathrm{NMR}\left(400.13 \mathrm{MHz}, \mathrm{CDCl}_{3}\right.$ ) $\delta_{\mathrm{H}}$ ppm: $2.72 .{ }^{13} \mathrm{C}$ NMR $\left(100.61 \mathrm{MHz},\left(\mathrm{CD}_{3}\right)_{2} \mathrm{SO}\right) \delta_{\mathrm{C}}$ ppm: 22.32; $114.23 ; 129.82 ; 158.31$.
2,3,9,10,16,17,23,24-Octamethyl-1,4,8,11,15,18,22,25-octaazaphthalocyaninatomagnesium (2). Magnesium chips (0.14 g, $5.8 \mathrm{mmol}$ ) were completely dissolved in boiling dry $n$-butanol $(7 \mathrm{~mL})$ in the presence of a catalytic amount of $I_{2}$. Then the compound $1(0.60 \mathrm{~g}, 3.8 \mathrm{mmol})$ was added to solution obtained and refluxed during $6 \mathrm{~h}$ (TLC-control: $\mathrm{Al}_{2} \mathrm{O}_{3}, \mathrm{C}_{6} \mathrm{H}_{6}$ ). The reaction mixture was cooled to room temperature and a $\mathrm{MeOH}: \mathrm{H}_{2} \mathrm{O}(10: 1$ $\mathrm{V} / \mathrm{V}$ ) mixture was added. A precipitate was filtered and washed with $\mathrm{MeOH}: \mathrm{H}_{2} \mathrm{O}(10: 1 \mathrm{~V} / \mathrm{V})$ and boiling ethanol. This yielded complex 2 (0.50 g, $80 \%) . m / z$ (MALDI TOF) (\%) 657 (60) [M+H], 679 (40) $[\mathrm{M}+\mathrm{Na}]^{+}$. UV-Vis (pyridine) $\lambda_{\max }(\lg \varepsilon) \mathrm{nm}: 350$ (4.05), 638 (3.90). ${ }^{1} \mathrm{H}$ NMR (600.13 MHz, [D $]$ Py) $\delta_{\mathrm{H}} \mathrm{ppm}$ : $2.14\left(\mathrm{~s}, \mathrm{CH}_{3}\right)$.

2,3,9,10,16,17,23,24-Octamethyl-1,4,8,11,15,18,22,25-octaazaphthalocyaninatozinc (3). A mixture of compound 1 (0.030 $\mathrm{g}, 0.19 \mathrm{mmol})$ and $\mathrm{Zn}$ (quinoline) $\mathrm{Cl}_{2}(0.47 \mathrm{~g}, 1.2 \mathrm{mmol})$ was irradiated in a microwave oven $(600 \mathrm{~W})$ during $15 \mathrm{~min}$. Then the reaction mixture was washed with $\mathrm{HCl}(36 \%)$ and water. Potassium hydroxide was added to solution obtained until the formation of precipitate. A dark green precipitate was filtered and washed with water and $\mathrm{MeOH}$. This yielded complex $3(0.023 \mathrm{~g}, 70 \%) . \mathrm{m} / \mathrm{z}$ (MALDI TOF) (\%): 697 (90) $[\mathrm{M}+\mathrm{H}]^{+}, 719$ (100) $[\mathrm{M}+\mathrm{Na}]^{+}, 735$ (50) $[\mathrm{M}+\mathrm{K}]^{+}, 758(20)\left[\mathrm{M}+\mathrm{CO}_{2}+\mathrm{H}_{2} \mathrm{O}\right]$. UV-Vis (Py) $\lambda_{\max } \mathrm{nm}(\lg \varepsilon)$ : 352 (3.86), 638 (3.80). ${ }^{1} \mathrm{H}$ NMR $\left(600.13 \mathrm{MHz},\left[\mathrm{D}_{5}\right] \mathrm{Py}\right) \delta_{\mathrm{H}} \mathrm{ppm}$ : $3.03\left(\mathrm{~s}, \mathrm{CH}_{3}\right)$.

\section{Results and Discussion}

5,6-Dimethylpyrazine-2,3-dicarbonitrile 1 was obtained from diaminomaleonitrile and 2,3-butanedione in the presence of cerium ammonium nitrate (CAN) (Scheme 1). In a typical literature procedure compound $\mathbf{1}$ was obtained under rigid conditions in boiling acid. ${ }^{[9,19]}$ Other approaches involve catalysis of process by copper-Schiff base complex with ordered mesoporous silica ${ }^{[20]}$ or using of $\alpha$-hydroxy ketone. ${ }^{[18]}$

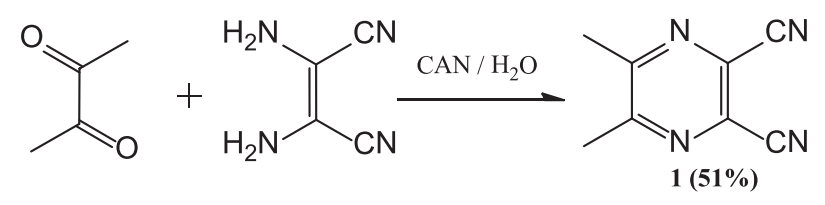

Scheme 1. Synthesis of 5,6-dimethylpyrazine-2,3-dicarbonitrile 1.

Using of CAN as a Lewis acid allows to synthesize target nitrile from easily accessible initial compounds under the mild conditions (room temperature). The yield of target complex was similar to presented in literature for acidfree approach (boiling ethanol, $55 \%$ ). ${ }^{[19]}$ Using of mixture of acetic acid and ethanol at $80{ }^{\circ} \mathrm{C}$ results in $85 \%$ yield of nitrile 1. ${ }^{[19]}$

As it was demonstrated earlier in literature, synthesis of porphyrazine complexes should be realized in anhydrous conditions for successful cyclotetramerization. ${ }^{[21]}$ So magnesium chips in boiling $n$-butanol were chosen for formation of template ion (Scheme 2). Target complex 2 was obtained in a good yield.

Zinc complex 3 was earlier obtained in one-step reaction between 2,3-diaminomaleodinitrile, 2,3-butanedione, urea and $\mathrm{ZnCl}_{2} \cdot{ }^{[22]}$ However the values of wavelengths were only mentioned. Authors didn't analyzed the data obtained for UV/Vis spectra in detail. 


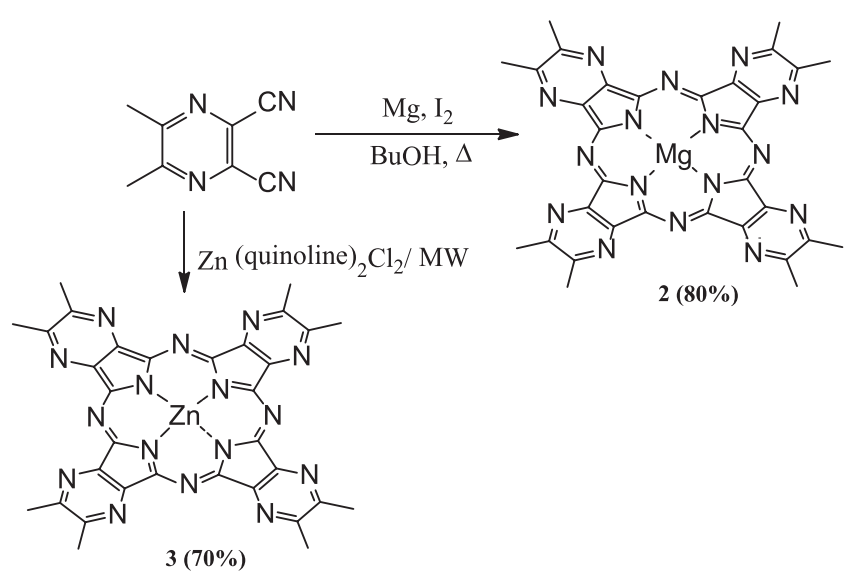

Scheme 2. Synthesis of porphyrazine complexes $\mathbf{2}$ and $\mathbf{3}$.

In the present work the reaction between nitrile $\mathbf{1}$ and $\mathrm{Zn}$ (quinoline) $\mathrm{Cl}_{2}$ salt was chosen to prepare target porphyrazine 3. $\mathrm{Zn}$ (quinoline) $\mathrm{Cl}_{2}$, prepared from zinc(II) chloride and quinoline, was utilized successfully for synthesis of different porphyrazine complexes. ${ }^{[17,21,23]}$ Unfortunately, thermal activation of compound $\mathbf{3}$ formation resulted in predominant polymerization process. For the first time the cyclization reaction between nitrile and $\mathrm{Zn}$ (quinoline) ${ }_{2} \mathrm{Cl}_{2}$ salt was activated by microwave irradiation. We found, that the yield of target complex 3 increases with increasing of amount of zinc salt. It can be explained by the template effect of zinc ion which can suppress the polymerization process. Using of $1: 1$ or $3: 1$ ratio of template:precursor results in yields about $30 \%$. Thus the best yield was reached using sixfold excess of the salt.

Novel porphyrazines 2, 3 were characterized by MALDI-TOF mass spectrometry. Besides the peaks of molecular

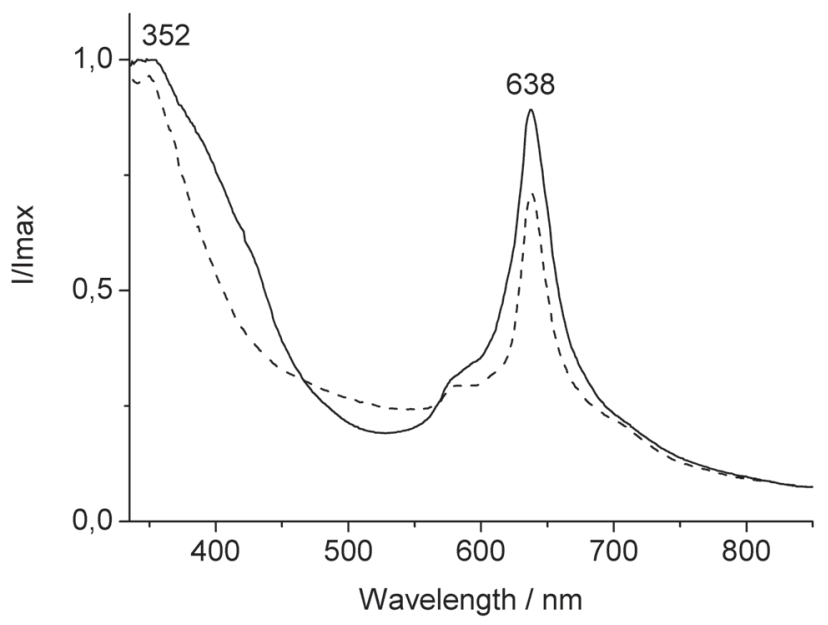

Figure 2. UV-Vis spectra of porphyrazine 2 (dashed line) and $\mathbf{3}$ (solid line) in pyridine.

ions, peaks of adducts with $\mathrm{Na}$ were also observed in mass spectra. For example the mass spectrum of magnesium complex was shown in Figure 1. Noteworthy, that in the case of complex $\mathbf{3}$, the increasing of coordination ability of zinc ion leads to increasing of quantity of peaks of adducts.

In the UV-Vis spectra of the target porphyrazine complexes, some peculiarities were observed (Figure 2). As it was earlier observed for thienoporphyrazine complexes ${ }^{[13]}$ the positions of Q- and B-bands were similar for zinc and magnesium central ions.

Full width at half maximum (FWHM) of Q-band reaches $43 \mathrm{~nm}$ for zinc complex. This value is twice higher, than for thienoporphyrazine complexes ${ }^{[6]}$ and resulted from strong aggregation of target porphyrazines even in coordinated solvents.

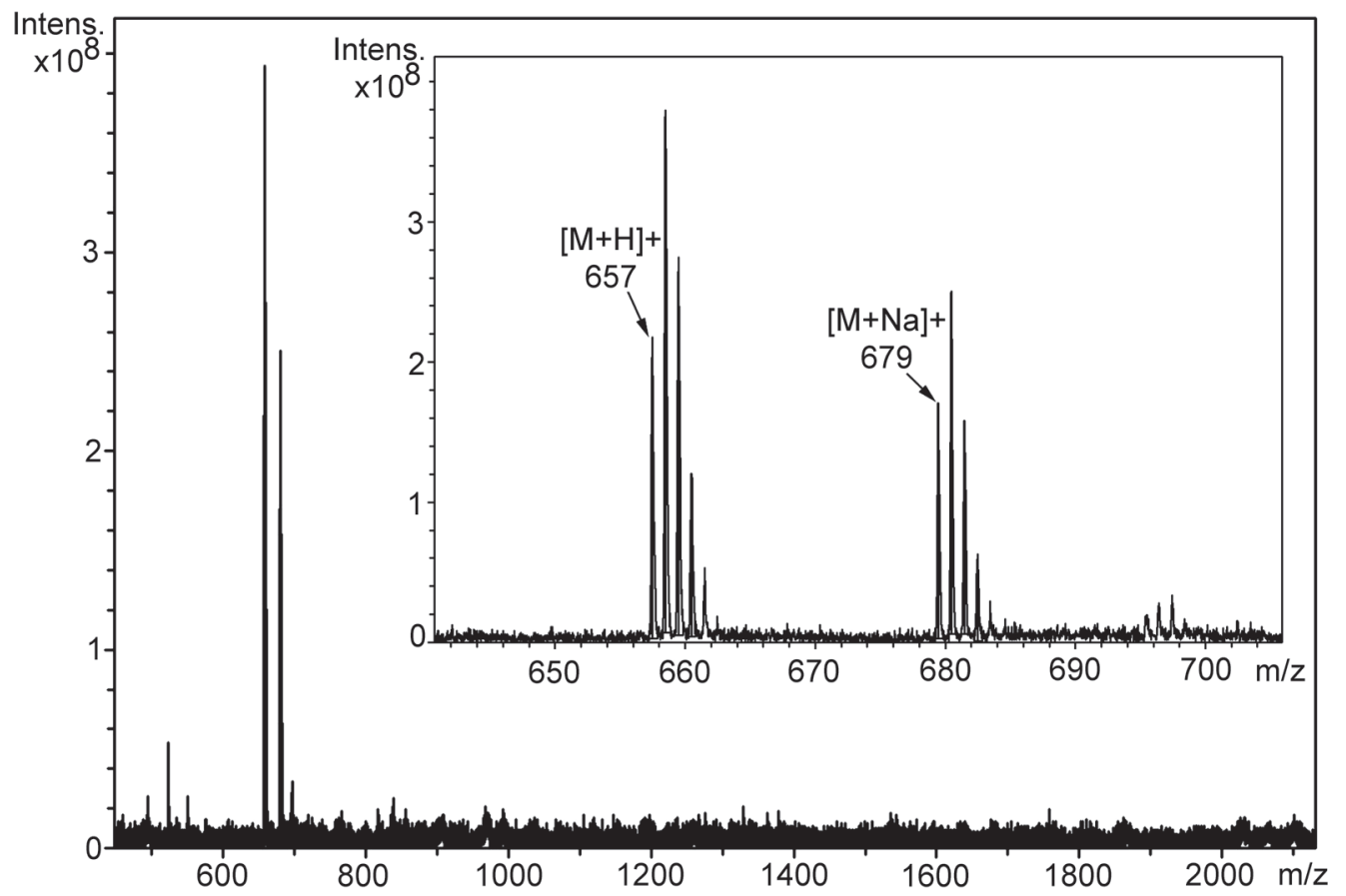

Figure 1. MALDI-TOF mass spectrum of magnesium compex 2. 

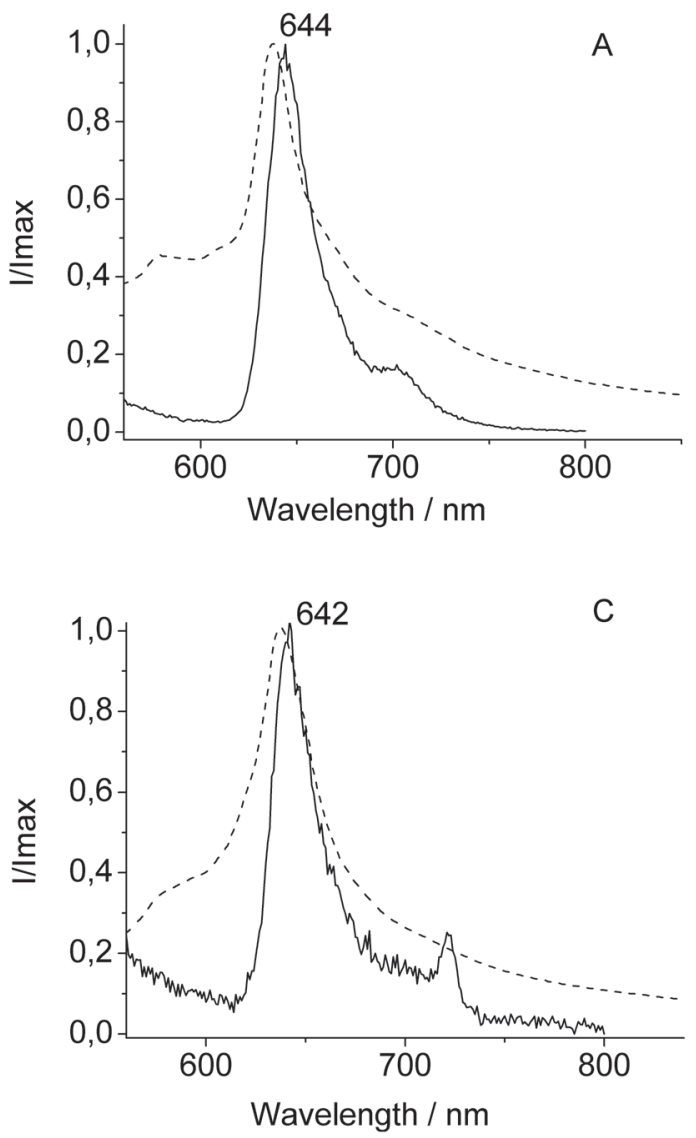
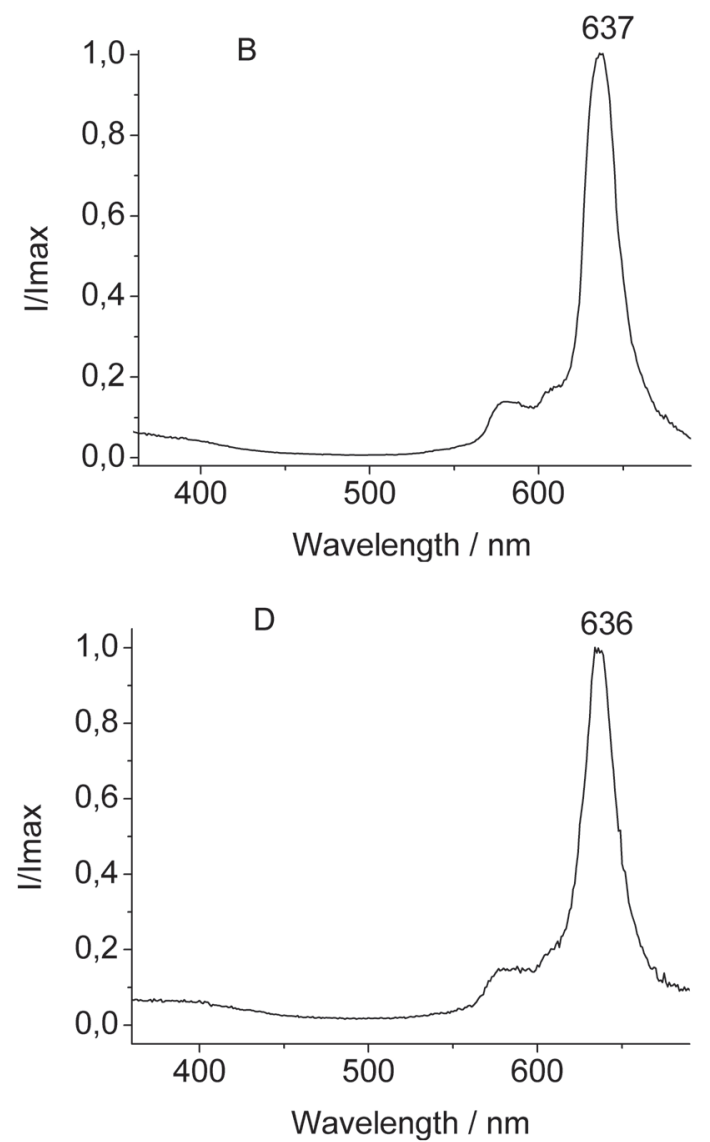

Figure 3. Fluorescence (solid line) and UV-Vis (dashed line) spectra $\left(\lambda_{\mathrm{ex}}=360 \mathrm{~nm}\right)$ of $\mathbf{2}$ in pyridine (A). Excitation spectrum $\left(\lambda_{\mathrm{em}}=700\right.$ $\mathrm{nm}$ ) of $\mathbf{2}$ in pyridine (B). Fluorescence (solid line) and UV/Vis (dashed line) spectra $\left(\lambda_{\mathrm{ex}}=360 \mathrm{~nm}\right.$ ) of $\mathbf{3}$ in pyridine (C). Excitation spectrum $\left(\lambda_{\mathrm{em}}=700 \mathrm{~nm}\right)$ of $\mathbf{3}$ in pyridine $(\mathrm{D})$.

In comparison with published earlier alkoxy and aryloxy substituted pyrazinoporphyrazines ${ }^{[2]}$ compounds $\mathbf{2}$ and $\mathbf{3}$ possess about $10 \mathrm{~nm}$ bathochromic shift of Q-band. This phenomenon can be explained by stronger donor effect of methyl groups comparing to alkoxy- and aryloxy- ones.

Fluorescence and excitation spectra were measured for target complexes (Figure 3). The Stokes shifts for Q-bands are very small. In contrast to absorption spectra, shapes of main bands in excitation spectra are narrow (FWHM is about $19 \mathrm{~nm}$ for zinc complex) and satellites are well-resolved. This follows from the fact that the excitation spectra correspond to the shape of nonaggregated complexes.

\section{Conclusions}

In conclusion, optimization of reaction conditions for preparation of pyrazine-2,3-dicarbonitrile, using CAN as a Lewis acid, was carried out. Novel methyl substituted tetrapyrazinoporphyrazine complexes were obtained in anhydrous medium with high yields. Target compounds were identified by MALDI-TOF mass-spectrometry, ${ }^{1} \mathrm{H}$ NMR spectroscopy and UV-Vis spectroscopy. For the first time the cyclization reaction of 5,6-dimethylpyrazine2,3-dicarbonitrile with $\mathrm{Zn}$ (quinoline) $\mathrm{Cl}_{2}$ salt was activated by microwave irradiation. It was shown, that the positions of the Q- and B-bands are similar for zinc and magnesium central ions. Fluorescence and excitation spectra were measured for target complexes. It was demonstrated, that excitation spectra correspond to the shape of nonaggregated complexes.

Acknowledgements. We thank Russian Foundation for Basic Research (Grant Nos. 16-33-60005, 15-33-21012, 1607-00961 and 15-03-05890) for financial support.

\section{References}

1. Miyoshi Y., Fujimoto T., Yoshikawa H., Matsushita M.M., Awaga K., Yamada T., Ito H. Organic Electronics 2011, 12, 239-243.

2. Schlettwein D., Woehrle D., Karmann E., Melville U. Chem. Mater. 1994, 6, 3-6.

3. Stuzhin P.A., Mikhailov M.S., Yurina E.S., Bazanov M.I., Koifman O.I., Pakhomov G.L., Travkin V.V., Sinelshchikova A.A. Chem. Commun. 2012, 48, 10135-10137.

4. Novakova V., Lásková M., Vavřičková H., Zimcik P. Chem. Eur. J. 2015, 21, 14382-14392.

5. Fox J.M., Katz T.J., Van Elshocht S., Verbiest T., Kauranen M., Persoons A., Thongpanchang T., Krauss T., Brus L. J. Am. Chem. Soc. 1999, 121, 3453-3459.

6. Dubinina T.V., Dyumaeva D.V., Trashin S.A., Sedova M.V., Karpo A.B., Krasovskii V.I., Tomilova L.G. Macroheterocycles 2012, 5, 149-156. 
7. Donzello M.P., Ercolani C., Gaberkorn A.A., Kudrik E.V., Meneghetti M., Marcolongo G., Rizzoli C., Stuzhin P.A. Chem. - Eur. J. 2003, 9, 4009-4024.

8. Hammer N.D., Lee S., Vesper B.J., Elseth K.M., Hoffman B.M., Barrett A.G.M., Radosevich J.A. J. Med. Chem. 2005, 48, 8125-8133.

9. Donzello M.P., Ercolani C., Novakova V., Zimcik P., Stuzhin P.A. Coord. Chem. Rev. 2016, 309, 107-179.

10. Kudrevich S.V., van Lier J.E. Coord. Chem. Rev. 1996, 156, 163-182.

11. Hamdoush M., Ivanova S.S., Koifman O.I., Kos'kina M., Pakhomov G.L., Stuzhin P.A. Inorg. Chim. Acta 2016, 444, 81-86.

12. de la Torre G., Vázquez P., Agulló-López F., Torres T. Chem. Rev. 2004, 104, 3723-3750.

13. Dubinina T.V., Dyumaeva D.V., Trashin S.A., Sedova M.V., Dudnik A.S., Borisova N.E., Tomilova L.G., Zefirov N.S. Dyes Pigm. 2013, 96, 699-704.
14. Alzeer J., Roth P.J.C., Luedtke N.W. Chem. Commun. 2009, 1970-1971.

15. PushkarevV.E.,KalashnikovV.V.,TrashinS.A.,BorisovaN.E.,Tomilova L.G., Zefirov N.S. Dalton Trans. 2013, 42, 12083-12086.

16. Kalashnikov V.V., Pushkarev V.E., Tomilova L.G. Mendeleev Commun. 2011, 21, 92-93.

17. Mørkved E.H., Afseth N.K., Kjøsen H. J. Porphyrins Phthalocyanines 2006, 10, 1301-1308.

18. Shaabani A., Maleki A. Chem. Pharm. Bull. 2008, 56, 79-81.

19. Rothkopf H.W., Wöhrle D., Müller R., Koßmehl G. Chemische Berichte 1975, 108, 875-886.

20. Bardajee G.R., Malakooti R., Jami F., Parsaei Z., Atashin H. Catalysis Commun. 2012, 27, 49-53.

21. Novakova V., Zimcik P., Miletin M., Vůjtěch P., Franzová Š. Dyes Pigm. 2010, 87, 173-179.

22. Maleki A., Rezayan A.H. Org. Chem. Int. 2014, 2014, 5.

23. Mørkved E.H., Andreassen T., Bruheim P. Polyhedron 2009 , 28, 2635-2640. 